\title{
Intravascular coagulation and $E$. coli septicaemia
}

\author{
F. E. PRESTON, R. G. MAlia, M. J. SWORN, AND E. K. BLACKBURN \\ From the University Departments of Haematology and Pathology, The Royal Infirmary, Sheffield
}

SYNOPSIS Eight patients with $E$. coli septicaemia had oliguric renal failure which was associated with $\vec{\circ}$ haematological evidence of intravascular coagulation. Five of these patients also had the charac- $\vec{\omega}$ teristic blood picture of microangiopathic haemolytic anaemia.

In an attempt to prevent further deposition of fibrin, intravenous heparin was administered to $\operatorname{six}$ 횽 patients, three of whom recovered fully and three died.

The diagnosis of intravascular coagulation was subsequently confirmed by histological examination $\stackrel{\sim}{\sim}$ of necropsy material and it is suggested that some of the complications of $E$. coli septicaemia may be $\vec{N}$ attributable to disseminated intravascular coagulation.

Experimental work in animals has demonstrated that bacterial endotoxin can, under certain well defined conditions, provoke changes in the coagulation mechanism and that these are associated with the deposition of fibrin within the microvasculature (Good and Thomas, 1953; Hjort and Rapaport, 1965). Although various haematological abnormalities have been described in patients with Gramnegative septicaemia, the precise pathogenesis of the reported findings has remained somewhat obscure. In the eight patients described here, $E$. coli septicaemia was associated with evidence of intravascular coagulation and severe renal impairment.

The eight patients were admitted to hospital between October 1970 and September 1971. A diagnostic blood culture was made in each case and all patients were treated with the appropriate antibiotic. Intravenous heparin was also administered to six patients, dosage being commenced at 2000 units and gradually increased to 6000 units, four-hourly. One patient, who did not receive heparin, was given intravenous fibrinogen and fresh frozen plasma.

\section{Methods}

Standard methods (Dacie and Lewis, 1968) were used for the routine haematological investigations. Prothrombin times were measured by the Quick onestage method and plasma thrombin times were measured by using human thrombin (Fibrindex, Ortho Pharmaceuticals Limited, 50 NIH units per $\mathrm{ml}$ ). One millilitre of $0.85 \%$ saline solution was added to a vial of Fibrindex and $\mathbf{0} \cdot 1 \mathrm{ml}$ of this solution was Received for publication 20 December 1972. added to a mixture of $0.1 \mathrm{ml}$ of $0.85 \%$ saline and $0.1 \mathrm{ml}$ citrated plasma in a water bath at $37^{\circ} \mathrm{C}$. Plasma fibrinogen was measured by the method of Ellis-Stransky (1961), normal levels being 200-400 $\mathrm{mg} / 100 \mathrm{ml}$. Euglobulin clot lysis time was estimateg cे by the method of Buckell (1958), the result being expressed in units by multiplying the reciprocal of the lysis time in minutes by 10000 . The normal range is 66-110 units. Plasma plasminogen was estimated by the method of Remment and Cohen (1949), as modified by Alkjaersig, Fletcher, and Sherry (1959). The normal range is $2 \cdot 0-4 \cdot 0$ units per ml. Fibrin/ fibrinogen degradation products (FDPs), in both serum and urine, were estimated using the Burroughs Wellcome kit. The sensitivity of the method is 1.25 $\mu \mathrm{g}$ per $\mathrm{ml}$, the normal range for serum being $0-20 \mu \mathrm{g}$ per $\mathrm{ml}$, while normal urine contains $0-1 \cdot 25 \mu \mathrm{g}$ per ml. Fibrinolytic inhibitors of urokinase were measured by the method of McNicol, Gale, and Douglas (1963), the normal range being 8-21 minutes. The blood urea was measured on an AutoAnalyzer (normal range: $20-40 \mathrm{mg} / 100 \mathrm{ml}$ ).

\section{Results}

Details of the individual patients are given in Table I. The haematological features at the time of the bacteriological diagnosis are presented in Table II. When the diagnosis of $E$. coli septicaemia was made, all patients were oliguric and their renal function was markedly impaired. A coagulation defect could be inferred in all patients by the presence of spontaneous bruising and also by the persistent oozing which occurred from venepuncture sites. 


\begin{tabular}{lllll}
\hline Case No. & Sex & Age & Predisposing Condition & Treatment \\
\hline 1 & F & 42 & Postcholecystectomy & Fibrinogen, antibiotics, fresh \\
& & & & Died \\
2 & F & 45 & Urinary tract infection & Antibiotics \\
3 & F & 48 & Urinary tract infection & Antibiotics, heparin \\
4 & F & 45 & Postcholecystectomy & Antibiotics, heparin \\
5 & M & 61 & Urinary tract infection & Antibiotics, heparin \\
6 & F & 50 & Not known & Antibiotics, heparin \\
7 & F & 2 wh & Urinary tract infection & Antibiotics, heparin \\
8 & F & 51 & Postsplenectomy & Antibiotics, heparin \\
\hline
\end{tabular}

Table I Summary of the patients

\begin{tabular}{|c|c|c|c|c|c|c|}
\hline Case No. & $\mathrm{Hb}(\mathrm{g} / 100 \mathrm{ml})$ & $\begin{array}{l}\text { Reticulocyte } \\
\text { Count }(\%)\end{array}$ & $\begin{array}{l}\text { Total WBC } \\
(\text { per } \mu l)\end{array}$ & $\begin{array}{l}\text { Platelet Count } \\
(\text { per } \mu l)\end{array}$ & Blood Film & $\begin{array}{l}\text { Urea } \\
(\mathrm{mg} / 100 \mathrm{ml})\end{array}$ \\
\hline 1 & $9 \cdot 1$ & 15 & 32000 & 40000 & $\begin{array}{l}\text { Leucoerythroblastic, burr cells and fragmented } \\
\text { erythrocytes }\end{array}$ & 290 \\
\hline 2 & $8 \cdot 0$ & 4 & 15000 & 75000 & $\begin{array}{l}\text { Leucoerythroblastic, burr cells and fragmented erythro- } \\
\text { cytes }\end{array}$ & 240 \\
\hline 3 & $7 \cdot 8$ & 5 & 9000 & 45000 & Occasional spherocytes & 300 \\
\hline 4 & $11 \cdot 2$ & 5 & 12000 & 20000 & Burr cells and fragmented erythrocytes & 194 \\
\hline 5 & $10 \cdot 0$ & 3 & 10000 & $<10000$ & Occasional spherocytes & 360 \\
\hline 6 & $10 \cdot 5$ & 0 & 1200 & $<10000$ & Burr cells and fragmented erythrocytes & 200 \\
\hline 7 & $15 \cdot 6$ & 3 & 18000 & 60000 & Occasional spherocytes & 120 \\
\hline 8 & $8 \cdot 7$ & 8 & 30000 & 35000 & Burr cells and fragmented erythrocytes & 220 \\
\hline
\end{tabular}

Table II Haematological features on presentation

Five of the eight patients had the characteristic blood picture of microangiopathic haemolytic anaemia. Platelet counts were all less than 80000 per $\mu 1$, while bone marrow examination in three patients showed normal or increased numbers of platelet-producing megakaryocytes.

Prothrombin times were found to be abnormal in six patients. In most instances these abnormalities could be corrected by the addition of 1:9 normal serum, indicating a deficiency of one or more of the serum clotting factors. The prothrombin times of two patients (cases 6 and 8, Table III) did not correct even after the addition of an equal volume of fresh normal plasma. This apparent inhibitor could not be detected in these two patients by prolongation of the thrombin clotting time, and, although we believe that it is almost certainly due to FDPs, its mode of action appears to be somewhat different from their well known antithrombin effect.

Plasma fibrinogen levels were normal in two patients, moderately reduced in three, and markedly reduced in three.

The six patients with low plasma fibrinogen concentrations had prolonged thrombin clotting times. In four of these patients the thrombin time could be corrected by the addition of an equal volume of normal plasma, but it was not possible to correct the remaining two (cases 1 and 5, Table III). This

\begin{tabular}{|c|c|c|c|c|c|c|c|c|}
\hline \multirow[t]{2}{*}{ Case No. } & \multirow{2}{*}{$\begin{array}{l}\text { One-stage } \\
\text { Prothrombin } \\
\text { Time (sec) }\end{array}$} & \multirow{2}{*}{$\begin{array}{l}\text { Thrombin Time } \\
\text { (sec.) }\end{array}$} & \multirow{2}{*}{$\begin{array}{l}\text { Fibrinogen } \\
(\mathrm{mg} / 100 \mathrm{ml})\end{array}$} & \multirow{2}{*}{$\begin{array}{l}\text { Euglobulin } \\
\text { Clot Lysis } \\
\text { (units) }\end{array}$} & \multirow{2}{*}{$\begin{array}{l}\text { Urokinase } \\
\text { Sensitivity } \\
\text { (min) }\end{array}$} & \multirow{2}{*}{$\begin{array}{l}\text { Plasminogen } \\
\text { (units/ml) }\end{array}$} & \multicolumn{2}{|c|}{ FDPs $(\mu g / m l)$} \\
\hline & & & & & & & Serum & Urine \\
\hline $\begin{array}{l}1 \\
2 \\
3 \\
4 \\
5 \\
6 \\
7 \\
8 \\
\text { Normal range }\end{array}$ & $\begin{array}{l}15(11)^{1} \\
13(12) \\
14(13) \\
16(11) \\
16(11) \\
31(11) \\
17(12) \\
\infty(12)\end{array}$ & $\begin{array}{r}11(7) \\
8(6) \\
5(5) \\
9(6) \\
12(7) \\
6(6) \\
10(6) \\
12(6)\end{array}$ & $\begin{array}{l}180 \\
145 \\
275 \\
85 \\
100 \\
200 \\
95 \\
50 \\
200-400\end{array}$ & $\begin{array}{r}33 \\
50 \\
<41 \\
55 \\
55 \\
14 \\
<17 \\
20 \\
66-166\end{array}$ & $\begin{array}{r}52 \\
>270 \\
28 \\
1800 \\
70 \\
235 \\
-\overline{1400} \\
10-21\end{array}$ & $\begin{array}{l}4 \cdot 3 \\
1 \cdot 25 \\
4 \cdot 8 \\
2 \cdot 8 \\
1 \cdot 8 \\
0 \cdot 5 \\
-2 \cdot 3 \\
2 \cdot 0-4 \cdot 0\end{array}$ & $\begin{array}{r}40 \\
80 \\
40 \\
160 \\
40 \\
40 \\
20 \\
80 \\
0-20\end{array}$ & $\begin{array}{l}5 \\
10 \\
5 \\
10 \\
20 \\
10 \\
10 \\
10 \\
0-1 \cdot 25\end{array}$ \\
\hline
\end{tabular}

Table III The coagulation fibrinolytic system 

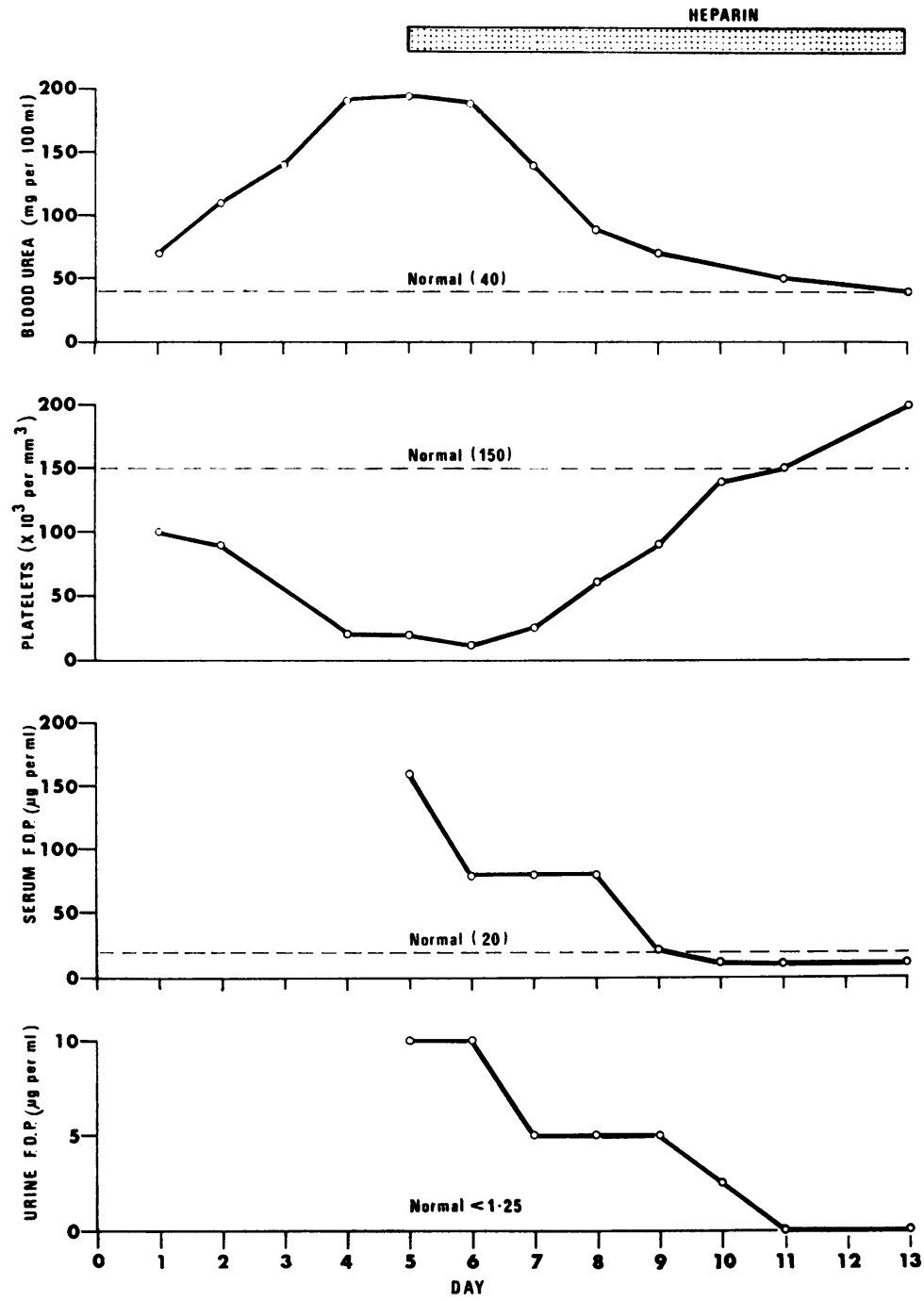

Fig. Case 4. Serial changes during treatment.

indicates, in these two, the presence of antithrombin activity which is presumably due to high molecular weight FDPs.

The plasma plasminogen was normal in two patients, elevated in two, and reduced in three.

Circulating activator was reduced in all eight patients and urokinase inhibitor activity increased in seven.

Serum fibrin/fibrinogen degradation products (FDPs) were significantly elevated in seven patients and urinary FDPs were increased in all eight. Following successful management the serum and urine FDPs fell in parallel with the level of blood urea. During the same period there was a progressive rise in the platelet count (Fig.).

A necropsy examination was made on the patients of who died. Histological evidence of intravascular $N$ coagulation was obtained in all cases, but there was $\underset{\mathrm{N}}{ }$ no constant pattern of distribution. The lungs were involved in three individuals, the kidneys in two, and the myocardium in two.

\section{Discussion}

There is ample evidence from experimental work in animals that intravascular coagulation and renal $\frac{\pi}{\mathbb{Q}}$ 


\begin{tabular}{|c|c|c|c|c|c|c|}
\hline Case No. & Heart & Kidneys & Liver & Lung & Gut & $\begin{array}{l}\text { Other Thromboembolic } \\
\text { Phenomena }\end{array}$ \\
\hline 1 & + & - & - & + & - & Splenic vein thrombosis \\
\hline 2 & $+t+$ & + & - & - & - & Recent splenic infarct \\
\hline 5 & - & - & + & - & - & - \\
\hline 6 & - & - & - & ++ & +++ & - \\
\hline 8 & - & + & - & ++ & - & Portal vein thrombosis \\
\hline
\end{tabular}

Table IV Histological evidence of intravascular coagulation

damage can be induced by two intravenous injections of bacterial endotoxin (Good and Thomas, 1953; Hjort and Rapaport, 1965). The classical SanarelliSchwartzman experiment consists of an initial priming injection followed, 18 to 24 hours later, by a second intravenous injection of the same endotoxin. Necropsy examination of the sacrificed animals reveals widespread intravascular fibrin which is particularly prominent in the glomerular tufts and splenic sinusoids. The importance of the initial injection is that it probably blockades the reticuloendothelial system which normally removes fibrin and other products of coagulation from the circulation (Ingram, 1969). The second injection promotes the coagulation mechanism and on this occasion the intermediate products of coagulation are not removed by the reticuloendothelial system. The process is thus completed with the formation of fibrin which is deposited in the microvasculature.

An experimental model which is more relevant to the clinical situation is produced by a continuous infusion of endotoxin which results in the deposition of fibrin within the glomerular vessels (Beller and Graeff, 1967; this deposition of fibrin is associated with a haemorrhagic diathesis which reflects the consumption of platelets, fibrinogen, and other clotting factors.

In the present study, haematological evidence of intravascular coagulation was obtained in all patients. Thus, elevated FDPs and thrombocytopenia were constant features, while fibrinogen depletion was noted in six of the eight patients. An increased concentration of serum FDPs reflects either fibrinogenolysis or fibrinolysis secondary to intravascular coagulation. Intravascular fibrinogenolysis is associated with increased circulating activator activity, measured by the euglobulin clot lysis time. Circulating activator was reduced in all eight patients and it appears, therefore, that the findings indicate intravascular coagulation with secondary fibrinolysis. Of interest is the increased activity of urokinase inhibitor, demonstrated in seven of the eight patients. A similar abnormality has previously been reported in the serum of individuals with various renal disorders (Bennett and Ogston, 1970) and it is possible that the development of this inhibitor is related to the deposition of fibrin within the glomerular capillaries.

All our eight patients had markedly impaired renal function at the time of bacteriological diagnosis. Although oliguric renal failure is a recognized complication of septicaemia, the precise mechanism by which it occurs has remained obscure. Recently, Clarkson, MacDonald, Fuster, Cash, and Robson (1970) have demonstrated the presence of fibrin within the glomerular capillaries of patients presenting with acute renal failure and these workers have suggested that intraglomerular coagulation may play an important role in the natural history of acute ischaemic renal failure. More recently it has been shown that urinary FDPs are frequently elevated in patients with many forms of glomerulonephritis and it has been suggested that they are often a reflection of local lysis of intraglomerular fibrin (Clarkson, MacDonald, Petrie, Cash, and Robson, 1971). In our study urinary FDPs were elevated in all patients, but since the serum FDPs were also raised, it is not possible to deduce whether the urinary FDPs were derived from the systemic circulation of whether they reflected intraglomerular lysis.

The abnormal bleeding tendency which was observed in all eight patients is a recognized complication of intravascular coagulation. The pathogenesis is complex and a number of factors are involved. Thrombocytopenia and coagulation factor deficiencies due to consumption are associated with the anticoagulant properties of the FDPs.

A further complication observed in five of the eight patients was a falling haemoglobin and the blood picture of microangiopathic haemolytic anaemia. The term was used by Brain, Dacie, and Hourihane (1962) to describe a haemolytic anaemia characterized by the presence of fragmented erythrocytes in the peripheral blood. These workers considered that the abnormal cells were the result of mechanical trauma occasioned on damaged vessel walls. More recently this hypothesis has been expanded to include damage on thin fibrin strands within the microvasculature (Bull, Rubenberg, Dacie, and Brain, 1968). This concept appears to receive 
support from our findings. The intravascular coagulation was related in time to the onset of renal failure and to the development of microangiopathic haemolytic anaemia. Moreover, reversal of the intravascular coagulation was accompanied by gradual disappearance of the burr cells and recovery of renal function.

In addition to the appropriate antibiotic therapy, and in an attempt to prevent further deposition of fibrin, intravenous heparin was administered to six of the eight patients. Intially 2000 units was injected and further injections were given at four hourly intervals, gradually increasing to 6000 units, four hourly. Formal laboratory control of the heparin therapy was not obtained, since such laboratory testing is of limited value in the presence of the acquired coagulation defects of intravascular coagulation defects of intravascular coagulation. Of the patients treated with heparin, three survived and three died. It is, of course, impossible to assess the value of heparin in such a small group of patients. It is noteworthy, however, that two of the patients who survived received heparin far earlier in the course of their illness than those who failed to recover, and we believe, therefore, that in order to be of therapeutic value heparin must be administered as early as possible and in maximum dosage.

The diagnosis of intravascular coagulation was subsequently confirmed by histological examination of necropsy,material of the five patients who died. There was no constant pattern of distribution of the intravascular fibrin. In this context, the findings of Regoeczi and Brain (1969) are possibly relevant. These workers, following an experimental study on induced intravascular coagulation in rabbits, suggested that the distribution of fibrin between the organs may be dependent on the speed of fibrin formation and hence the size of microclot formed. The absence of demonstrable fibrin in the kidneys of three patients is somewhat surprising, although Clarkson and his coworkers (1970) have demonstrated that techniques more refined than light microscopy may be required for the detection of fibrin in acute renal failure.

There is close similarity between the clinical, haematological, and pathological features of the patients with microangiopathic haemolytic anaemia, described here, and those of children with the haemolytic-uraemic syndrome. Although aetiological factors are often difficult to elicit in these children, the striking clinical resemblance which they bear to patients with $E$. coli septicaemia suggests to us that the haemolytic-uraemic syndrome is another example, in man, of the Schwartzman-Sanarelli reaction.

The mechanism whereby $E$. coli septicaemia induces a state of intravascular coagulation is uncertain. The introduction of bacterial endotoxin $\underline{\text { 을 }}$ into an experimental animal will induce platelet $\Rightarrow$ clumping and release of platelet factor 3 (Horowitz, $\stackrel{0}{\rightarrow}$ Des Prez, and Hook, 1962). This, in the presence of calcium ions, factor $V$ and factor $X$, can initiate the 흘 formation of thrombin via the extrinsic coagulation $\frac{5}{5}$ mechanism. Moreover, endotoxin also activates $\stackrel{\mathbb{Q}}{\varrho}$ factor XII which is the starting point of the main intrinsic coagulation pathway (McKay and Muller- $\overrightarrow{0}$ Berghaus, 1968).

It would appear from our findings that intra- $\overrightarrow{\vec{\omega}}$ vascular coagulation is a frequent complication of $\stackrel{\sim}{S}$ E. coli septicaemia. Microthrombi may be deposited $\widehat{\bar{O}}$ anywhere within the microvasculature and the ensuing necrosis may give rise to a variety of clinical iv and pathological effects. The vascular occlusion may $\vec{N}$ be associated with a bleeding diathesis and we $O$ believe, therefore, that at least some of the compli- 윽 cations of $E$. coli septicaemia may be directly attributable to this disturbance of the coagulation- T fibrinolytic system.

We wish to thank the medical staff of the United Sheffield Hospitals for the opportunity of studying $\vec{\theta}$ the patients under their care. We also wish to thand w Wellcome Reagents Ltd for supplying us with the FDP assay kits.

References

Alkjaersig, N., Fletcher, A. P., and Sherry, S. (1959). The mechanism of $\frac{O}{8}$ clot dissolution by plasmin. J. clin. Invest., 38, 1086-1095.

Beller, F. K., and Graeff, H. (1967). Deposition of glomerular fibrin $\overline{\bar{B}}$ in the rabbit after infusion with endotoxin. Nature (Lond.), 215, 295-296.

Bennett, N. B., and Ogston, D. (1970). Inhibitors of the fibrinolytic enzyme system in renal disease. Clin. Sci., 39, 549-551.

Brain, M. C., Dacie, J. V., and Hourihane, D. O'B. (1962). Microangiopathic haemolytic anaemia: the possible role of vascular lesions in pathogenesis. Brit. J. Haemat., 8, 358-374.

Buckell, M. (1958). The effect of citrate on euglobulin methods of estimating fibrinolytic activity. J. clin. Path., 11, 403-405.

Bull, B. S., Rubenberg, M. L., Dacie, J. V., and Brain, M. C. (1968). Microangiopathic haemolytic anaemia: mechanisms of redcell fragmentation: in vitro studies. Brit. J. Haemat., 14, 643652.

Clarkson, A. R., MacDonald, M. K., Fuster, V., Cash, J. D., and Robson, J.S. (1970). Glomerular coagulation in acute ischaemic renal failure. Quart. J. Med., 39, 585-599.

Clarkson, A. R., MacDonald, M. K., Petrie, J. J. B., Cash, J. D., and Robson, J. S. (1971). Serum and urinary fibrin/fibrinogen degradation products in glomerulonephritis. Brit. med. J., 3, G 447-451.

Dacie, J. V., and Lewis, S. M. (1968). Practical Haematology, 4th ed. Chürchill, London.

Ellis, B. C., and Stransky, A. (1961). A quick and accurate method for $W$ the determination of fibrinogen in plasma. J. Lab. clin. Med., 58, 477-488.

Good, R. A., and Thomas, L. (1953). Prevention of the local and generalised Schwartzman reactions with heparin. J. exp. Med., 97, 871-888.

Hjort, P. F., and Rapaport, S. I. (1965). The Schwartzman reaction: pathogenetic mechanisms and clinical manifestations. Ann. Rev. Med., 16, 135-168.

Horowitz, H. I., Des Prez, R. M., and Hook, E. W. (1962). Effects of bacterial endotoxin on rabbit platelets. J. exp. Med., 116, 619633. 
Ingram, G. I. C. (1969). The defibrination syndrome. In Recent Advances in Blood Coagulation, edited by L. Poller, p. 267. Churchill, London.

McKay, D. G., and Muller-Berghaus, G. (1968). Hageman factor (HF) and the generalized Schwartzman reaction (GSR). Fed. Proc., 27, 436.

McNicol, G. P., Gale, S. B., and Douglas, A. S. (1963). In-vitro and in-vivo studies of a preparation of urokinase. Brit. med. J., 1, 909-915

Regoeczi, E., and Brain, M. C. (1969). Organ distribution of fibrin in disseminated intravascular coagulation. Brit. J. Haemat., 17, 73-81.

Remment, L. F., and Cohen, P. P. (1949). Partial purification and properties of a proteolytic enzyme of human serum. J. biol. Chem., 181, 431-448.

\section{Reports and Bulletins prepared by the Association of Clinical Biochemists}

The following reports and bulletins are published by the Association of Clinical Biochemists. They may be obtained from The Administrative Office, Association of Clinical Biochemists, 7 Warwick Court, Holborn, London, WC1R 5DP. The prices include postage, but air mail will be charged extra. Overseas readers should remit by British Postal or Money Order. If this is not possible the equivalent of 50p is the minimum amount that can be accepted.

SCIENTIFIC REPORTS

3 Automatic Dispensing Pipettes. An assessment of 35 commercial instruments 1967 P. M. G. BROUGHTON, A. H. GOWENLOCK, G. M. WIDDOWSON, and K. A. AHLQUIST 80p (\$2)

4 An Evaluation of five Commercial Flame Photometers suitable for the Simultaneous Determination of Sodium and Potassium March 1970 P. M. G. BROUGHTON and J. B. DAWSON 80 p (\$2)

\section{SCIENTIFIC REVIEWS}

1 The Assessment of Thyroid Function March 1971 F. V. FLYNN and J. R. HOBBS $60 p(\$ 1.50)$

2 Renal Function Tests Suitable for Clinical Practice January 1972 F. L. MTTCHell, N. VEALL, and R. W. E. WATTS $60 \mathrm{p}(\$ 1.50)$

\section{TECHNICAL BULLETINS}

9 Determination of Urea by AutoAnalyzer November 1966 RUTH M. HASLAM 40p (\$1)

11 Determination of Serum Albumin by AutoAnalyzer using Bromocresol Green Oçtober $1967^{\circ}$ B. E. NORTHAM and G. M. WIDDOWSON 40p (\$1)

13 An Assessment of the Teahnicon Type II Sampler Unit March 1968 B. C. GRAY and G. K. MCGOWAN 40p (\$1)

14 Atomic Absorption Spectroscopy. An outline of its principles and a guide to the selection of instruments May 1968 J. B. DAWSON and P. M. G. BROUGHTON 40p (\$1)

15 A Guide to Automatic Pipettes (2nd edition) June 1968 . P. M. G. BROUGHTON 40p (\$1)
16 A Guide to Automation in Clinical Chemistry May 1969 P. M. G. BROUGHTON 60p (\$1.50)

17 Flame Photometers (2nd edition) 1969 P. WILDING $60 \mathrm{p}(\$ 1.50)$

18 Control Solutions for Clinical Biochemistry (4th edition) March 1970 P. M. G. BROUGHTON 60p (\$1.50)

19 Spectrophotometers. A comparative list of low-priced instruments readily available in Britain May 1970 C. E. WILDE and P. SEWELL 60p (\$1.50)

20 Quantities and Units in Clinical Biochemistry June 1970 P. M. G. BROUGHTON 60p (\$1.50) More than 30 copies in units of 10 at 20p

21 Filter Fluorimeters: A comparative list of 18 instruments September 1970 H. BRAUNSBERG and s. S. BROWN $60 \mathrm{p}(\$ 1.50)$

22 Bilirubin standards and the Determination of Bilirubin by Manual and Technicon AutoAnalyzer Methods January 1971 BARBARA BILLING, RUTH HASLAM, and N. WALD 60p (\$1.50)

23 Interchangeable Cells for Spectrophotometers and Fluorimeters September 1971 E. S. BROWN and A. H. GOWENLOCK 60p $(\$ 1.50)$

24 Simple Tests to Detect Poisons March 1972 B. w. MEADE et al. $60 \mathrm{p}(\$ 1.50)$

25 Blood Gas Analysers May 1972 k. DIxoN 60p (\$1.50)

26 Kits for Enzyme Activity Determination September 1972 s. B. ROSALKI and D. TARLOW 80p $(\$ 2.00)$

27 Assessment of Pumps Suitable for Incorporation into Existing Continuous Flow Analytical Systems November 1972 A. FLECK et al 60p (\$1.50) 